\title{
ASSESSING THE IMPACT OF SEISMIC RISK MITIGATION AT THE URBAN SCALE ON COMMUNITY RESILIENCE AND HOUSING RECOVERY
}

\author{
A. BASAGLIA ${ }^{1 *}$, A. APRILE ${ }^{2}$, E. SPACONE $^{1}$ AND L. PELA் ${ }^{3}$ \\ ${ }^{1}$ Department of Engineering and Geology (INGEO) \\ University “G. D'Annunzio" of Chieti-Pescara \\ Viale Pindaro 42, 65127 Pescara, Italy \\ Email: \{alberto.basaglia*, enrico.spacone\}@unich.it, www.ingeo.unich.it (*corresponding author) \\ ${ }^{2}$ Department of Engineering \\ University of Ferrara \\ Via Saragat 1, 44122 Ferrara, Italy \\ email: alessandra.aprile@unife.it,www.de.unife.it \\ ${ }^{3}$ Department of Civil and Environmental Engineering \\ Universitat Politècnica de Catalunya (UPC-BarcelonaTech) \\ Campus Nord, Carrer de Jordi Girona, 1, 3, 08034 Barcelona, Spain \\ Email: luca.pela@upc.edu -Web page: http://www.upc.edu
}

Keywords: Community Resilience, Housing Recovery, Seismic Risk, Risk Mitigation

\begin{abstract}
European historical city centers are particularly prone to natural disasters. This is due to the fragility of structures that often times do not comply with seismic codes; the high constructions' density that causes induced damage; and the historical relevance of buildings that makes difficult the enacting of mitigation strategies.
\end{abstract}

In Italy, major earthquake caused extensive damages over the last century. Seismic events have a huge impact on the nation's economy growth due to direct and indirect impacts, such as for example the high reconstruction costs or the business interruption spread out over a long period, respectively. In addition, the duration of recovery can affect the population wellbeing and cause permanent displacement. For this reason, the preventive planning of disaster management strategies are crucial to mitigate the damage and enhance resilience. Proposed strategies have to be effective and economically sustainable.

In this paper, two towns affected by the 2012 Northern Italy Earthquake are chosen to analyze the reconstruction process. Using information published on the town journal, relevant aspects of the community resilience are highlighted. In particular, the housing recovery, i.e. the return of displaced people to a permanent housing solution is investigated.

Then, a suite of seismic mitigation strategies is proposed for both cities, taking into account the peculiarity of the built environment and the damage distribution available thanks to the postevent buildings' inspection. The effectiveness of the proposed strategies is assessed through a cost-benefit analysis, highlighting optimal solutions to reduce the economic and social losses. 


\section{INTRODUCTION}

Major earthquakes are among the deadliest and costliest natural disasters both worldwide [1] and in Europe [2] in the past decades. In Italy, four major seismic sequences occurred since 2009 (L'Aquila 2009, Northern Italy 2012, Central Italy 2016-2017 and Ischia 2017) causing more than 650 casualties and injuring almost 2400 people $[3,4,5,6]$.

The high social impact can be associated to the high vulnerability of the built environment. In fact, the first seismic zonation map, i.e. the identification of the potential seismic hazard and probability of occurrence, covering the entire Italian territory was developed only in 2003 [7] and adopted in the Design Code of 2008 [8]. On the other hand, the vast majority of buildings were designed pre-2003 and therefore without following earthquake-resistant design (ERD) concepts, see Figure 1 [9].
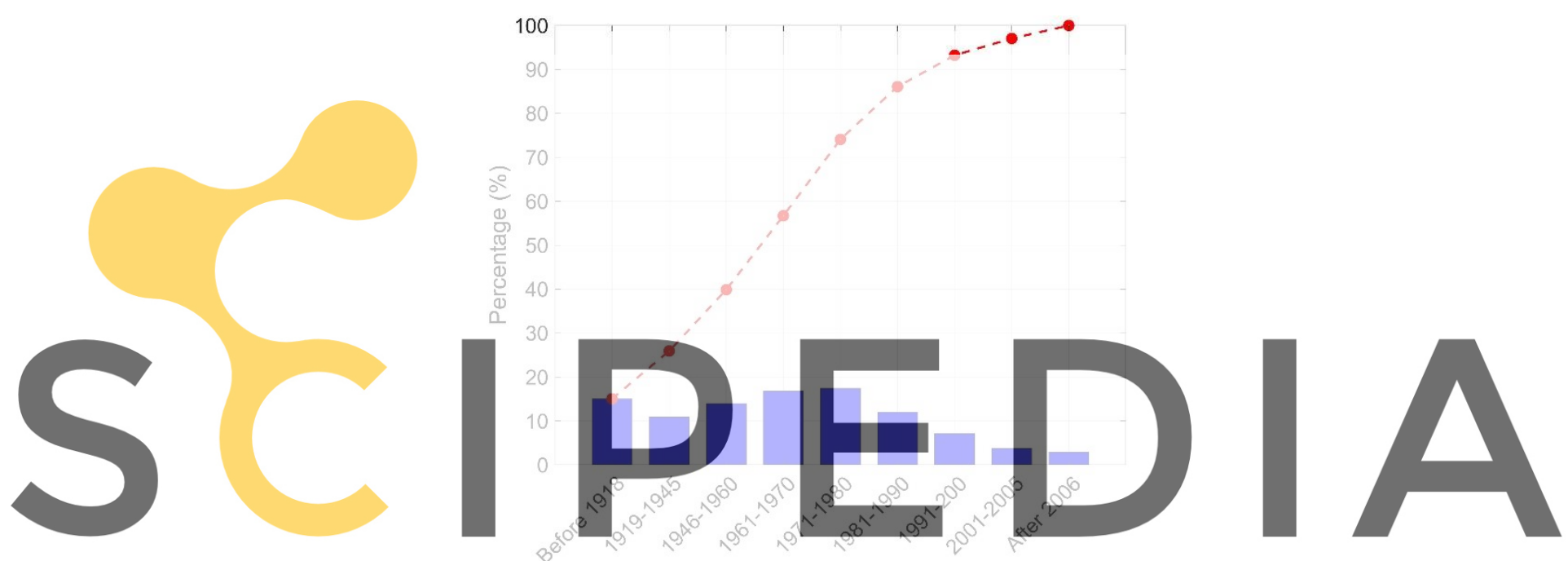

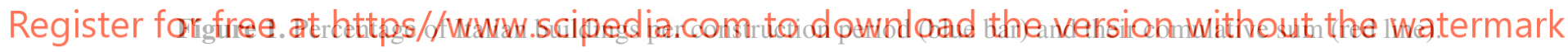

This vulnerability led to significant direct and indirect losses in the occurrence of major earthquakes. Direct losses include the repair and reconstruction costs [10,11], while indirect losses may be referred to the business interruption [12] and the cost of providing temporary housing for the people displaced [13].

In particular, when people are displaced from their home, two different solutions are generally adopted: they are provided with a temporary shelter, called PMAR (Prefabricated Adaptable and Movable Residences), or they are given a monetary contribution called CAS (Contribution for Accommodation Self-determined) in case they decide to independently find a housing solution. These housing solutions are defined as "temporary", even if they may last for several years, affecting the population wellbeing, causing identity loss [14] or, in extreme cases, the depopulation [15].

All the aforementioned aspects highlight the need of preventive seismic risk mitigation strategies at the urban scale, in order to reduce the socio-economic impact of earthquakes. Recently, the Italian Government issued a tax break called SismaBonus [16] up to 85\% in 10 years of the cost invested by owners of houses or flats in increasing the seismic performance of the buildings they live in. To easily quantify the actual and target seismic performance of 
buildings, guidelines have been introduced that classify buildings into seven classes depending on a safety index $I S-V$ [17], see Table 1 . IS $-V$ is evaluated by performing structural analyses according to the Code provisions [18].

Table 1. Risk classification depending on the Safety Index IS-V.

\begin{tabular}{cc}
\hline Safety Index & IS-V Class \\
\hline $100 \%<\mathrm{IS}-\mathrm{V}$ & $\mathrm{A}^{+}{ }_{\text {IS-V }}$ \\
\hline $80 \% \leq \mathrm{IS}-\mathrm{V}<100 \%$ & $\mathrm{~A}_{\mathrm{IS}-\mathrm{V}}$ \\
\hline $60 \% \leq \mathrm{IS}-\mathrm{V}<80 \%$ & $\mathrm{~B}_{\text {IS-V }}$ \\
\hline $45 \% \leq \mathrm{IS}-\mathrm{V}<60 \%$ & $\mathrm{C}_{\text {IS-V }}$ \\
\hline $30 \% \leq \mathrm{IS}-\mathrm{V}<45 \%$ & $\mathrm{D}_{\text {IS-V }}$ \\
\hline $15 \% \leq \mathrm{IS}-\mathrm{V}<30 \%$ & $\mathrm{E}_{\mathrm{IS}-\mathrm{V}}$ \\
\hline $\mathrm{IS}-\mathrm{V}<15 \%$ & $\mathrm{~F}_{\text {IS-V }}$ \\
\hline
\end{tabular}

In this paper, the recovery process of two cities affected by the 2012 Northern Italy earthquake (NIE) is presented. Data are collected through the cities' municipal journal. Then, the effect of preventive seismic mitigation strategies is investigated thanks to the post-seismic buildings' inspection. A cost-benefit analysis is performed considering both socio-economic losses.

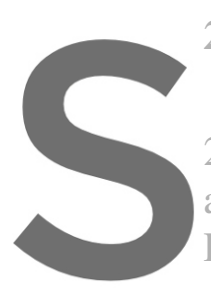

\section{DOCUMENTING}

Two major seismic 29 $9^{\text {th }}, 2012$. These earthe

almost 15000 homeless

Protection Agency to prov

solutions could be found.
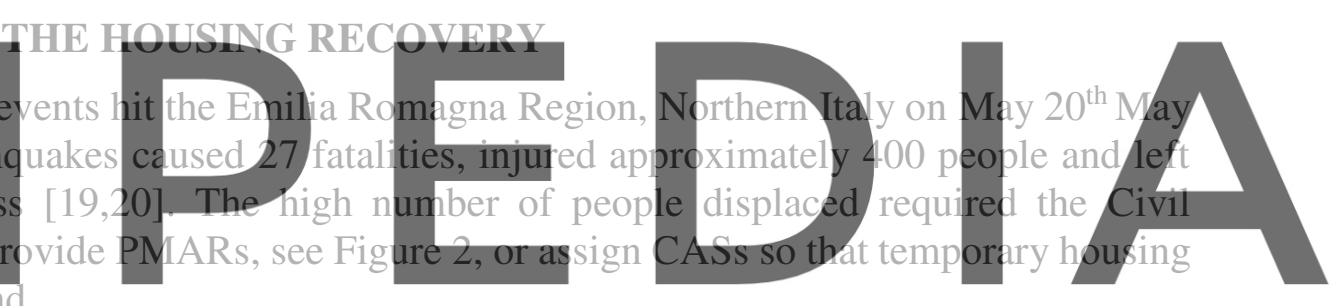

Register for free at https//www.scipedia.com to download the version without the watermark

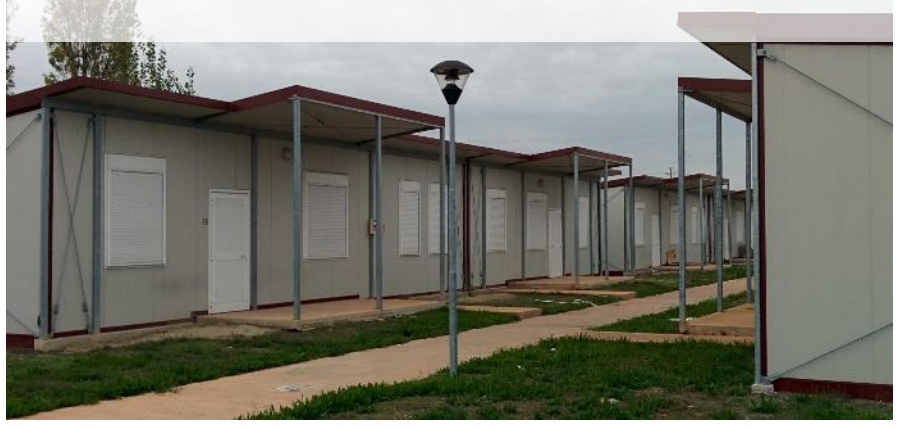

Figure 2. PMARs installed after the 2012 NIE.

The area affected by the NIE is highly industrialized and it is reasonable to assume that this aspect significantly contributed to the disaster recovery, as people were able to retain their job. Yet, one of the most important aspects for the recovery is the return to their pre-event home or a permanent housing solution. This is generally referred to as housing recovery [13]. Few studies have already evaluated the trend of people living in a PMAR or being assigned a CAS. 
For example, Mannella et al. (2017) [21] analyzed the evolution of people displaced after the 2009 L'Aquila earthquake until the end of 2016. Then, Carnelli and Frigerio (2017) [22] studied the number and social indicators of people living in PMARs in the city of Mirandola until mid2016. It is worth noting that, even considering a time span of seven years, the full recovery was not observed, meaning that the issue of people displaced by major earthquakes may last for a very long time after the event.

In this study, the housing recovery of Concordia sulla Secchia and Mirandola, two cities affected by the 2012 NIE is documented. Data are collected through the municipal journals, the "Concordia Comune" [23] and "Indicatore Mirandolese" [24], see Figure 3, which are freely accessible online.

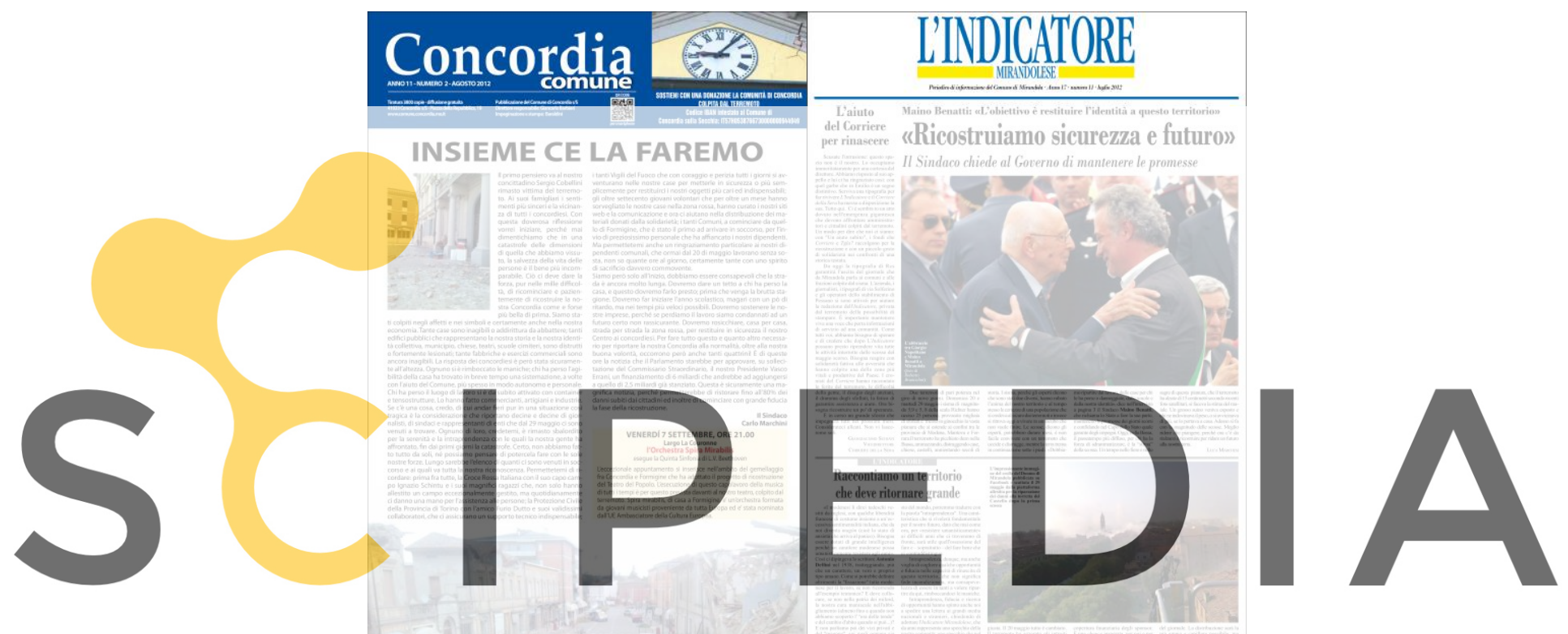

Register for free at https//www.scipedia.com to download the version without the watermark Figure 3. First issue of the (left) Concordia Comune and (right) Indicatore Mirandolese after the 2012 NIE.

The housing recovery is associated to the number of people either living in a PMAR or being assigned a CAS. No information was found on the number of people staying in a hotel and similar lodging establishments or that decided to move out from the city, and therefore are not included in the study. Results are shown in Figure 4.

After the 2012 NIE occurrence, in the city of Concordia sulla Secchia slightly less than three hundred people (94 households) lived in a PMAR and almost nineteen hundred people (756 households) were assigned a CAS. In the city of Mirandola, the number of homeless was significantly higher, as almost a thousand people (286 households) lived in a PMAR and slightly less than 7500 people (2964 households) were assigned a CAS. In 2017, approximately five years after the NIE, all households living in a PMAR in both cities had returned to a permanent housing solution. On the other hand, $13 \%$ and $7 \%$ of people displaced were still assigned a CAS in Concordia sulla Secchia and Mirandola, respectively. These findings highlight the very long process of housing recovery that may take several years, causing distress in the population and affecting the community resilience, i.e. the return to the pre-event performance [25]. 
It is worth noting that, despite these data are considered reliable given that they are provided by a journal issued by the municipality itself, they are scattered throughout the years, making it difficult to understand the trends.
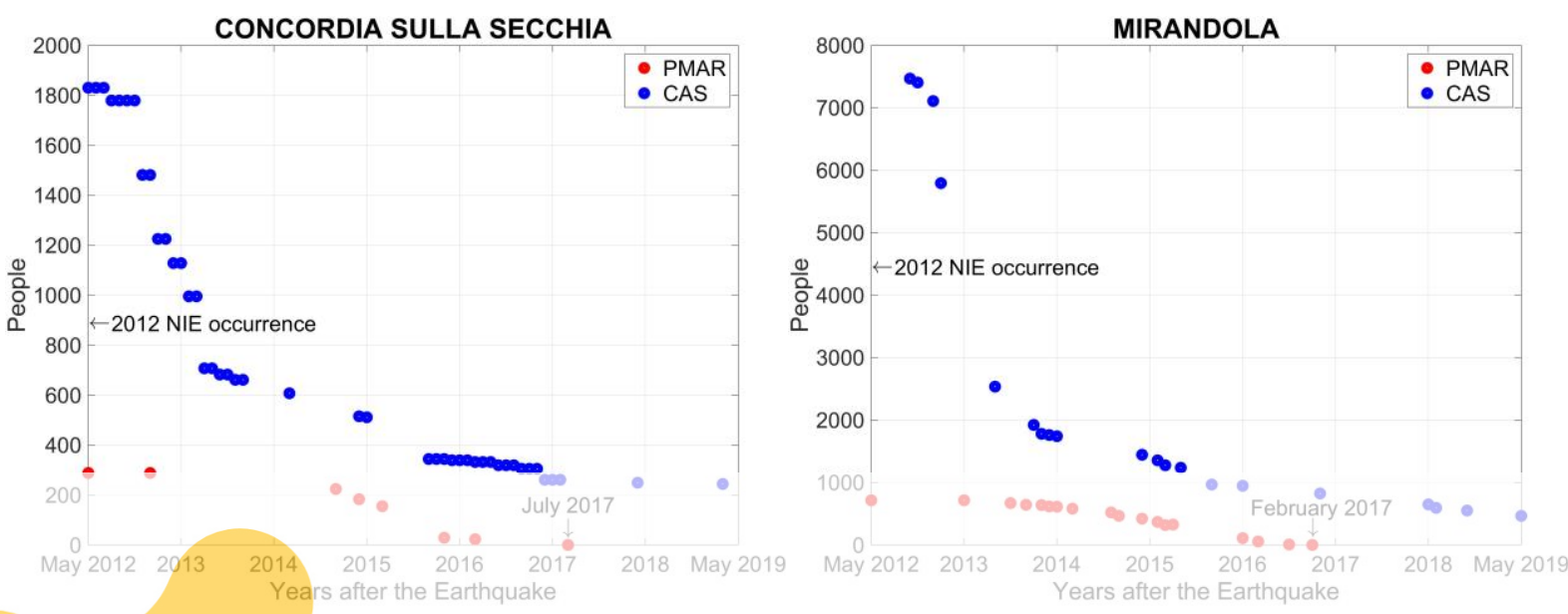

Figure 4. Housing recovery for (left) Concordia sulla Secchia and (right) Mirandola after the 2012 NIE.

Very few information are available regarding the cost of PMARs and CAS. A report states that each PMAR cost approximately 26.000€ [26] while another puts the cost at 125.000€ [24],

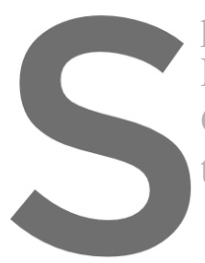
probably including the Regarding the CAS, son Comune" [22], see Tab to the people displace Table 2
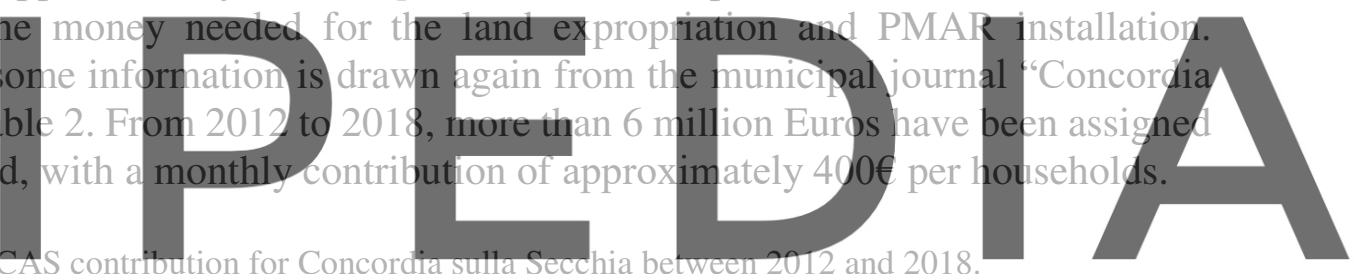

Register for free at https//www.Selipedia.com to dofmidgld the velfsibsilhwidtiout the watermark

\begin{tabular}{ccc} 
May - July 2012 & 545737 & 756 \\
\hline August - November 2012 & 1458690 & 735 \\
\hline December 2012 - January 2013 & 651074 & 612 \\
\hline February - March 2013 & 546177 & 506 \\
\hline April - May 2013 & 497894 & 466 \\
\hline June - July 2013 & 411320 & 411 \\
\hline August - September 2013 & 322162 & 292 \\
\hline October - November 2013 & 309440 & 282 \\
\hline December - January 2014 & 299510 & 273 \\
\hline February - May 2014 & 441800 & 194 \\
\hline January - March 2016 & 120168 & 142 \\
\hline April - June 2016 & 119782 & 140 \\
\hline July - September 2016 & 117950 & 137 \\
\hline October - December 2016 & 114891 & 132 \\
\hline January - March 2017 & 108920 & 126 \\
\hline April - June 2017 & 96873 & 108 \\
\hline July - September 2017 & 86341 & 105 \\
\hline October - December 2018 & 71709 & 101
\end{tabular}




\section{SEISMIC RISK MITIGATION AT THE URBAN SCALE}

Given the high impact that major earthquakes have on affected communities, that require several years to recover and have significant associated losses, preventive seismic mitigation strategies become crucial. These strategies have to be effective but also economically sustainable.

As for early 2020, 140.6 and 470.5 million Euros have been assigned for the repair and reconstruction of residential buildings in the city of Concordia sulla Secchia and Mirandola, respectively [27]. Considering the total area of buildings, it leads to an investment of approximately $1500 € / \mathrm{m}^{2}$ to rebuild or retrofit a structure up to the current Code provision in terms or ERD concepts (class AIS-V of Table 1). However, for existing buildings that were designed without ERD concepts, the seismic retrofit may not be the optimal solutions in monetary terms. For example, installing bond-beams and/or tied rods to guarantee the box-like behavior of unreinforced masonry (URM) buildings or preventing the shear failure of reinforced concrete $(\mathrm{RC})$ columns with fiber-reinforced polymers may prevent collapse and therefore guarantee a sufficient safety level. This concept can be referred to as class upgrade (CU). A CU raise the considered building up a $I S-V$ class and it therefore is expected to undergo a lower damage in the occurrence of an earthquake. Considering the five damage levels defined in the European Macroseismic Scale (EMS-98) [28], CUs are described in Table 3.

Table 3. Summary and description of the considered class upgrades for buildings.
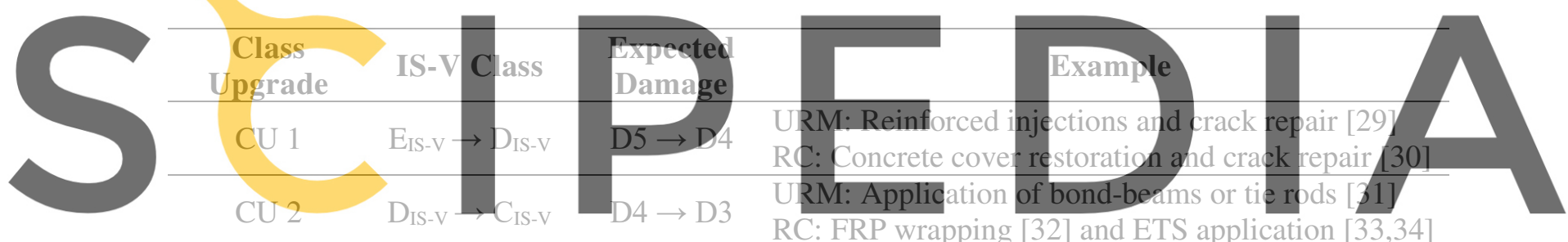

RC: FRP wrapping [32] and ETS application [33,34]

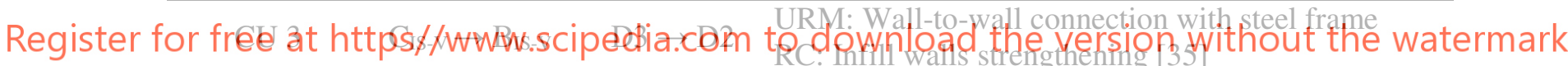

\begin{tabular}{llll}
\hline CU 4 & BIS-V $\rightarrow$ A IS-V & D2 $\rightarrow$ D1 & $\begin{array}{l}\text { URM: Reduction of in-plan slab flexibility } \\
\text { RC: Reduction of in-plan slab flexibility }\end{array}$ \\
\hline CU 5 & $\mathrm{A}_{\text {IS-V }} \rightarrow \mathrm{A}^{+}{ }_{\text {IS-V }}$ & D1 $\rightarrow$ D0 & $\begin{array}{l}\text { URM: Walls reinforcement with TRM [35] } \\
\text { RC: Introduction of new resistant system [36] }\end{array}$ \\
\hline
\end{tabular}

Damage level D5 is associated to complete collapse and D0 is associated to no damage. Class FIS-v of Table 1 is not considered as the very poor seismic performance makes it unfeasible to undertake any strengthening work.

For each CU, a nominal cost of $300 € / \mathrm{m}^{2}$ is assumed based on the Authors' professional experience. Information about the buildings' construction type, floor area and observed damage are available thanks to the Da.D.O. (Database of Damage Observed) online database [37] that collects data about the post-event inspections that assess the damage and evaluate the accessibility. Only URM and RC buildings are considered, as they represent almost the entirety of the sample. The structural type and damage distributions for Concordia sulla Secchia and Mirandola are shown in Figure 5. 

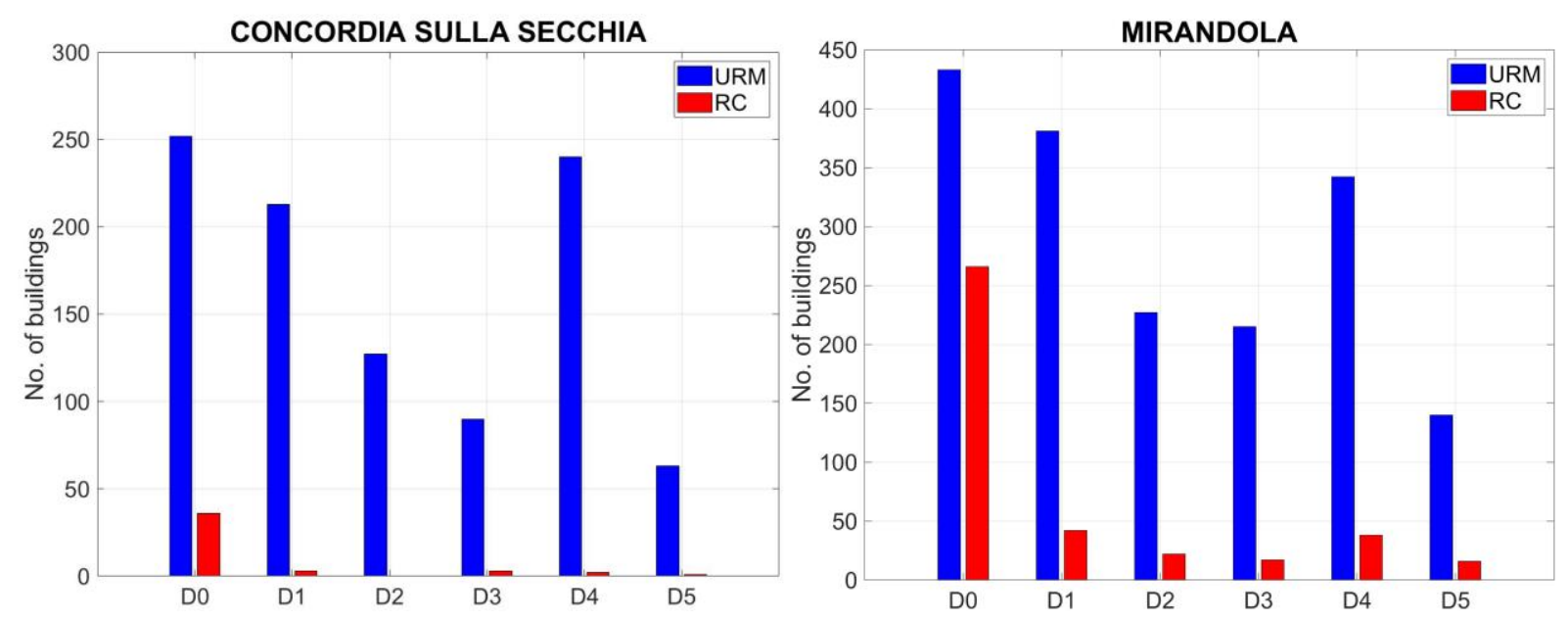

Figure 5. Structural type and damage distribution for (left) Concordia sulla Secchia and (right) Mirandola.

Repair and replacement cost are assumed based on a recent study about the reconstruction after the 2009 L'Aquila earthquakes [38] and are defined for five damage levels, see Table 4.

Table 4. Assumed repair and replacement costs.
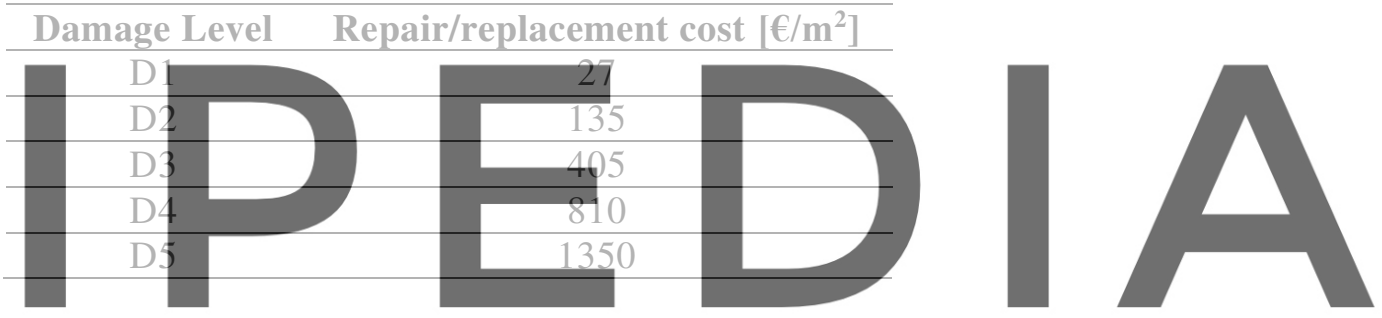

A cost-benefit analysis of seismic mitigation strategies is performed for Concordia sulla

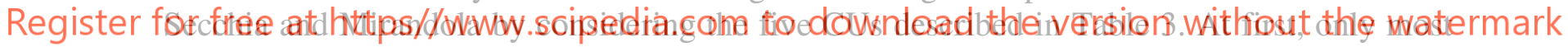
damages buildings are reinforced and the cost of a preventive strengthening is compared with that of the repair and replacement costs. The analysis is carried on until all buildings have been retrofit so that they are expected not to undergo any damage in the occurrence of an event similar to the NIE. Results of the analysis are shown in Figure 6.
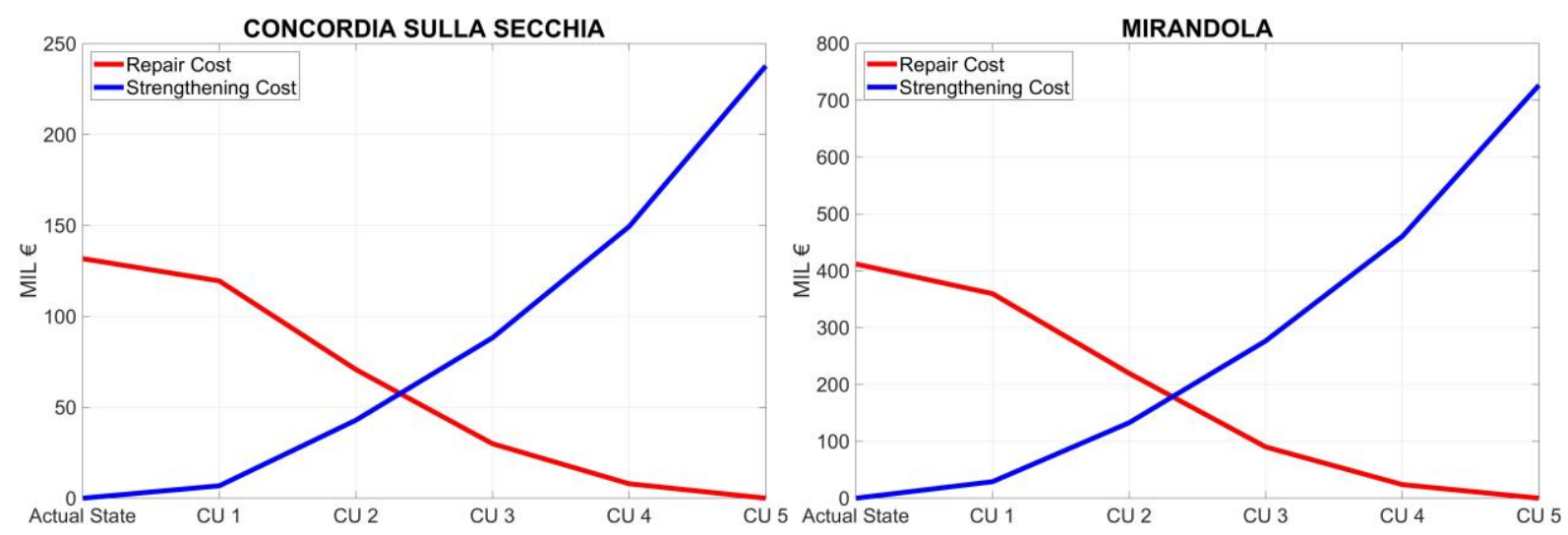

Figure 6. Cost-benefit analysis of various CUs for (left) Concordia sulla Secchia and (right) Mirandola. 
Obtained results show that the optimal solution (the point where the strengthening and the repair cost curves meet) is between the $2^{\text {nd }}$ and $3^{\text {rd }} \mathrm{CU}$. In terms of $I S-V$ Class, the optimal solution is between class $\mathrm{C}_{\text {IS-V }}(45 \% \leq \mathrm{IS}-\mathrm{V}<60 \%)$ and $\mathrm{B}_{\mathrm{IS}-\mathrm{V}}(60 \% \leq \mathrm{IS}-\mathrm{V}<80 \%)$. These findings are in line with provisions of Italian Guidelines [39] that suggest for existing buildings to adopt strengthening works that allow them to withstand up to $60 \%$ of the expected seismic actions.

In addition, it is noted that estimated repair and replacement costs for residential buildings of Concordia sulla Secchia and Mirandola, obtained with values of Table 4, are comparable to those actually assigned [27], see Table 5.

Table 5. Comparison between estimated and assigned repair and replacement costs for Concordia sulla Secchia and Mirandola.

\begin{tabular}{ccc}
\hline City & $\begin{array}{c}\text { Estimated repair and } \\
\text { replacement costs [MIL } €]\end{array}$ & $\begin{array}{c}\text { Assigned repair and } \\
\text { replacement costs [MIL } € \text { ] }\end{array}$ \\
\hline Concordia sulla Secchia & 131.8 & 140.6 \\
\hline Mirandola & 412 & 470.5 \\
\hline
\end{tabular}

The positive effect of seismic mitigation strategies is assessed also in terms of the social impact. In particular, the expected number of injuries and fatalities is evaluated for the same CUs of Figure 6. The casualty estimation is performed using the approach defined by Zuccaro

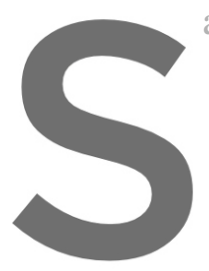
and Cacace (2012) [40]. Results are shown in
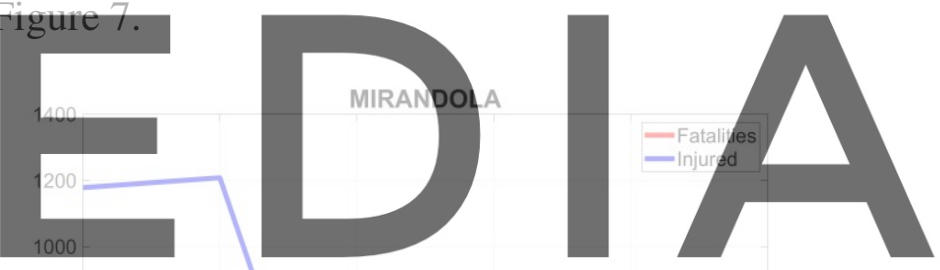

Register fö̆r free at https//www.scipedia.com to download the version without the watermark
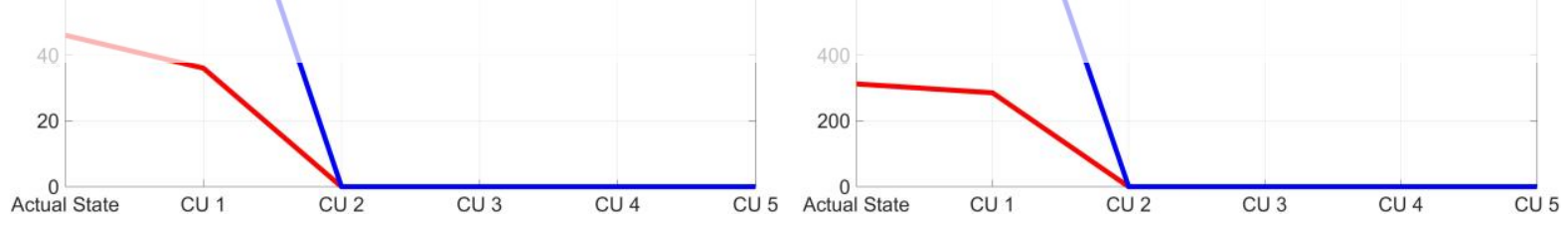

Figure 7. Injuries and fatalities estimation for (left) Concordia sulla Secchia and (right) Mirandola.

Obtained results show that with 2 CUs an event similar to the 2012 NIE is expected not to cause any injury or fatality. These findings further support those obtained with the cost-benefit analysis in Figure 6.

\section{SUMMARY AND CONCLUSIONS}

In this paper, the benefit of preventive seismic mitigation strategies at the urban scale is presented and evaluated. In Italy, these strategies are crucial due to the age of the built environment, that in most cases is not designed following ERD concepts and therefore may undergo significant damage event with earthquakes of moderate intensities. 
Damage is considered in terms of both social and economic losses. Social losses include loss of lives and injuries, but also the people displaced who are in need of a new housing solution. In particular, people displaced may need several years to return to a permanent home, with consequences on their wellbeing and the overall community resilience. Economic losses include both the repair and replacement costs and the business interruption. In order to reduce losses, preventive mitigation strategies have to be implemented. These could range from localized strengthening works to a complete retrofit.

This paper presented a data collection of the housing recovery of two cities affected by the 2012 NIE thanks to the information included in the municipal journals. It is observed that, more than seven years after the earthquake, a considerable portion of the population hasn't returned to a permanent housing solutions yet.

Then, the concept of class upgrade is introduced and used to perform a cost-benefit analysis of a suite of mitigation strategies. By comparing the strengthening and the repair and replacement costs, the optimal solutions is found. This solution is in line with the current Code provision for existing buildings and may be used to enact policies at the Stakeholders' level to promote a "culture of mitigation". A significant contribution in this way is given by the recently introduced SismaBonus, a tax break in 10 years for the seismic strengthening of residential buildings that could make the work more affordable. For this reason, the use of risk assessment methods at the urban scale [41] is crucial to clearly identify the more vulnerable areas of a city and in this way prioritize the strengthening works.
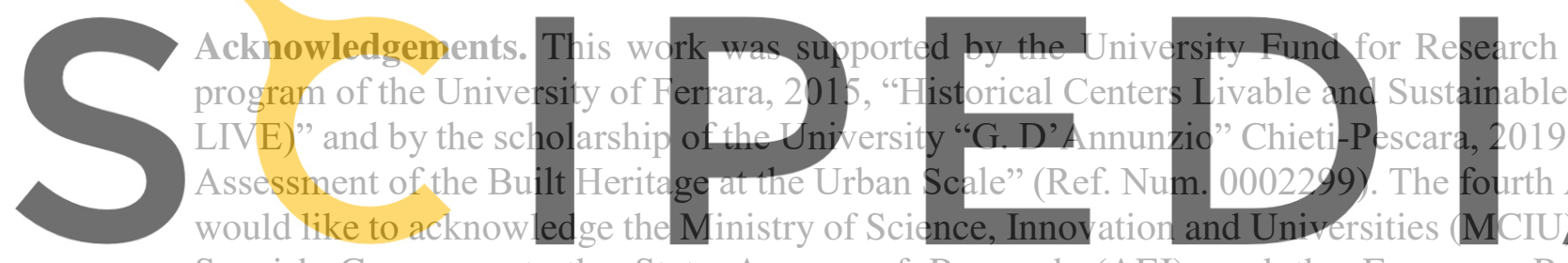

Spanish Government, the State Agency of Research (AEI), and the European Regional

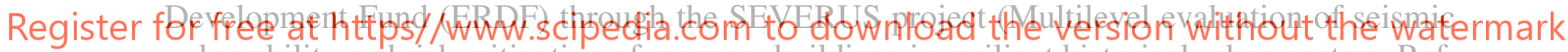
vulnerability and risk mitigation of masonry buildings in resilient historical urban centres, Ref. Num. RTI2018-099589-B-I00).

\section{REFERENCES}

[1] CRED. Natural disasters 2018. An opportunity to prepare. Available at: https://www.cred.be/sites/default/files/CREDNaturalDisaster2018.pdf (2019).

[2] PreventionWeb. Europe - Disaster Statistics. Region Profile for Natural Disasters from 1980 - 2008. Available at: https://www.preventionweb.net/english/countries/statistics/ind ex_region.php?rid=3 (2008).

[3] Alexander, D. and Magni, M. Mortality in the L'Aquila (central Italy) earthquake of 6 April 2009. PLoS Curr (2013) 5:e50585b8e6efd1.

[4] Mucciarelli, M., and Liberatore, D. Guest editorial: the Emilia 2012 earthquakes, Italy. Bull Earthq Eng (2014) 12:2111-2116.

[5] Fiorentino, G., Forte, A., Pagano, E., Sabetta, F., Baggio, C., Lavorato, D., Nuti, C. and Santini S. Damage patterns in the town of Amatrice after August 24th 2016 Central Italy earthquakes. Bull Earthq Eng (2018) 16:1399-1423.

[6] Briseghella, B., Demartino, C., Fiore, A., Nuti, C., Sulpizio, C., Vanzi, I., Lavorato, D. and 
Fiorentino, G. Preliminary data and field observations of the 21st August 2017 Ischia earthquake. Bull Earth Eng (2019) 17:1221-1256.

[7] Bellicoso, A. Italian Anti-Seismic Legislation and Building Restoration. Int Journal for Housing Science (2011) 35: 137-147.

[8] Ministero delle Infrastrutture e dei Trasporti. Norme Tecniche per le Costruzioni. Gazzetta Ufficiale (2008) 29. Italian.

[9] Istat. Edifici residenziali. Istituto Nazionale di Statistica (2011). Available at: https://www.istat.it/. Italian.

[10] Di Giacomo, M. I costi dei terremoti in Italia. Centro Studi Consiglio Nazionale Ingegneri (2014). Italian.

[11] Ufficio Valutazione Impatto. Terremoti. L'Aquila, Reggio-Emilia, Centro Italia: politiche e risorse per ricostruire il Paese. Senato della Repubblica (2017). Italian.

[12] Rose, A. Defining and measuring economic resilience to disasters. Disaster Prevention and Management (2004) 13: 307-314.

[13] Peacock, W.G., Dash, N., Zhang, Y. and Van Zandt, S. Post-Disaster Sheltering, Temporary Housing and Permanent Housing Recovery. In: H. Rodríguez et al. (Eds): Handbook of Disaster Research. Springer, Cham (2018), pp. 569-594.

[14] Giuliani, A.R., Mattei, A., Santilli, F. Well-Being and Perceived Quality of Life in Elderly People Displaced After the Earthquake in L'Aquila, Italy. J Community Health (2014) 39: 531-537.

[15] Di Giovanni, G. and Chelleri, L. Why and how to build back better in shrinking territories? Disaster Preventio

[16] Agenzia delle Entrate. Available at: https:

17] Ministero delle In Rischio Sismico Delle Costruzioni. Decreto Ministeriale

[18] Ministero delle Infrastrutture e dei Trasporti. Aggiornamento delle «Norme Tecniche per

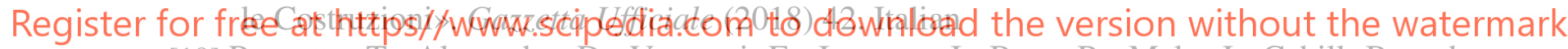

[19] Rossetto, T., Alexander, D., Verrucci, E., Ioannou, I., Borg, R., Melo, J., Cahill, B. and Kongar, I. The 20th May 2012 Emilia Romagna earthquake (2012) EPICentre Field observation report.

[20] Ioannou, I., Borg, R., Novelli, V., Melo, J., Alexander, D., Kongar, I., Verrucci, E., Cahill, B. and Rossetto, T. The 29th May 2012 Emilia Romagna earthquake (2012) EPICentre Field observation report.

[21] Mannella, A., Di Ludovico, M., Sabino, A., Prota, A., Dolce, M. and Manfredi, G. Analysis of the population assistance and returning home in the reconstruction process of the 2009 L'Aquila earthquake. Sustainability (2017) 9: 1395.

[22] Carnelli, F. and Frigerio, I. A socio-spatial vulnerability assessment for disaster management: Insights from the 2012 Emilia earthquake (Italy). Sociologia urbana $e$ rurale (2016) 11: 22-44.

[23] Municipality of Concordia sulla Secchia. Concordia Comune. Available at: https://www.comune.concordia.mo.it/. Italian.

[24] Municipality of Mirandola. Indicatore Mirandolese. Available at: http://www.comune.mirandola.mo.it/. Italian.

[25] Bruneau, M., Chang, S.E., Eguchi, R.T., Lee, G.C. et al. A framework to quantitatively 
assess and enhance the seismic resilience of communities. Earthquake spectra (2003) 19: 733-752.

[26] Battista C. Ricostruzione, ecco quanto costano i moduli abitativi provvisori. ModenaToday (2013). Available at: http://www.modenatoday.it/. Italian.

[27] Regione Emilia-Romagna. Open Ricostruzione. Monitora gli interventi per la ricostruzione in Emilia-Romagna. Available at: https://openricostruzione.regione.emilia-romagna.it/.

[28] Grünthal, G. European Macroseismic Scale 1998. Cahiers du Centre Européen de Géodynamique et de Séismologie (1998) 15.

[29] Modena, C., Valluzzi, M.R., da Porto, F. and Casarin, F. Structural Aspects of The Conservation of Historic Masonry Constructions in Seismic Areas: Remedial Measures and Emergency Actions. Int Jour of Architectural Heritage (2001) 5: 539-558.

[30] Biondini, F., Camnasio, E. and Titi, A. Seismic resilience of concrete structures under corrosion. Earthquake Engng Struct Dyn (2015) 44: 2445-2466.

[31] Frumento, S., Giovinazzi, S., Lagomarsino, S. and Podestà, S. Seismic retrofitting of unreinforced masonry buildings in Italy. In: Proceedings of the 2006 NZSEE Conference (2006), Napier, New Zealand.

[32] Perrone, M., Barros, J.A. and Aprile, A. CFRP-based strengthening technique to increase the flexural and energy dissipation capacities of RC columns. Journal of composites for construction (2009) 13: 372-383.

[33] Breveglieri, M., Barros, J.A., Aprile, A. and Ventura-Gouveia, A. Strategies for numerical modeling the behavior of RC beams strengthened in shear using the ETS technique. Engineering Structures (2016) 128:296-315.

[34] Breveglieri, M., Aprile, A. and Barros, J.A. RC beams strengthened in shear using the Embedded Through-Section technique: Experimental results and analytical formulation. Composites Part B: Engineering (2016) 89: 266-281.

[35] Gulinelli, P., Aprile, A., Rizzoni, R., et al. A Fe Model for TRM Reinforced Masonry Walls with Interface Effects. In Key Engineering Materials (2019) 817: 57-64.

[36] Zerbin, M. and Aprile, A. Sustainable retrofit design of RC frames evaluated for different seismic demand. Earthq. Struct (2015) 9: 1337-1353.

[37] Dolce, M., Speranza, E., Giordano, F., Borzi, B., Bocchi, F., Conte, C., Di Meo, A., Faravelli, M. and Pascale, V. Observed damage database of past Italian earthquakes: the Da. DO WebGIS. Bollettino di Geofisica Teorica ed Applicata (2019) 60: 141-164.

[38] De Martino, G., Di Ludovico, M., Prota, A., Moroni, C., Manfredi, G. and Dolce, M. Estimation of repair costs for RC and masonry residential buildings based on damage data collected by post-earthquake visual inspection. Bull Earthq Eng (2017) 15: 1681-1706.

[39] Il Presidente della Repubblica. Decreto legge 6 giugno 2012, n. 74: interventi urgenti per le popolazioni colpite dagli eventi sismici nelle province di Bologna, Modena, Ferrara, Mantova, Reggio Emilia e Rovigo il 20 e il 29 maggio 2012. Gazzetta Ufficiale (2012) 131. Italian.

[40] Zuccaro, G. and Cacace, F. Seismic casualty evaluation: The Italian model, an application to the L'Aquila 2009 event. In: R. Spence et al. (Eds): Human casualties in earthquakes. Springer, Dordrecht (2011), pp. 171-184.

[41] Basaglia, A., Aprile, A., Spacone E. and Pilla F. Performance-based Seismic Risk Assessment of Urban Systems. International Journal of Architectural Heritage (2018) 12: 1131-1149. 